Purdue University

Purdue e-Pubs

Purdue CIBER Working Papers

Krannert Graduate School of Management

$1-1-2007$

\title{
The Quality of Accounting Information in Politically Connected Firms
}

Paul K. Chaney

Vanderbilt University

Mara Faccio

Purdue University

David Parsley

Vanderbilt University

Follow this and additional works at: http:// docs.lib.purdue.edu/ciberwp

Chaney, Paul K.; Faccio, Mara; and Parsley, David, "The Quality of Accounting Information in Politically Connected Firms" (2007). Purdue CIBER Working Papers. Paper 53.

http://docs.lib.purdue.edu/ciberwp/53

This document has been made available through Purdue e-Pubs, a service of the Purdue University Libraries. Please contact epubs@purdue.edu for additional information. 


\title{
The Quality of Accounting Information in Politically Connected Firms
}

\author{
Paul Chaney \\ Vanderbilt University \\ Mara Faccio \\ Purdue University \\ David Parsley \\ Vanderbilt University
}

2007-008 


\title{
The Quality of Accounting Information in Politically Connected Firms
}

\author{
PAUl K. Chaney, Mara FACCIO, AND DAVID C. PARSLEY*
}

Recent studies have documented systematic exchanges of favors between politicians and firms, and that connected firms, on average gain from political ties. Since these ties are often to a top manager or large shareholder, agency problems are likely more severe for politically connected firms. Moreover, in the case of political ties, the costs of lower quality disclosures may be mitigated. Empirically, we find that the quality of earnings reported by politically connected firms is significantly poorer than that of similar non-connected companies. Additionally, among connected firms, those that have stronger political ties have the poorest accruals quality. This evidence suggests that managers of connected firms appear to be less sensitive to market pressures to increase the quality of information. This choice seems to be justified in that lower quality reported earnings is associated with higher cost of debt only for the non-politically connected firms in the sample.

${ }^{*}$ Chaney and Parsley are from the Owen Graduate School of Management, Vanderbilt University. Faccio is from the Krannert School of Management, Purdue University. We thank the Financial Markets Research Center for financial support, Art Durnev, Christian Leuz, Mike Weisbach, and seminar participants at Florida State University, the University of Illinois at Urbana-Champaign, Vanderbilt University, and the Banff Conference on Emerging Trends in Corporate Governance for comments. 
A number of studies have shown that poor earnings quality results in more frequent enforcement actions by the SEC (Dechow, Sloan, and Sweeney, 1996), lawsuits (Francis, Philbrick, and Schipper, 1994), a higher cost of both debt and equity capital (Francis, LaFond, Olsson, and Schipper, 2004, 2005), and poor future returns (Chan, Chan, Jegadeesh, and Lakonishok, 2006). Nonetheless, Fan and Wong (2002) find that the earnings of Asian family firms have limited information content. They argue that this result is driven by an entrenchment effect, where family firms have more incentive and capability to manipulate earnings in order to expropriate value from minority shareholders. In a similar vein, Leuz (2006) documents that U.S. firms with highly concentrated ownership systematically engage in earnings management.

One aspect not considered by existing studies is how the quality of accounting information reported by publicly traded firms is affected by the existence of political connections. ${ }^{1}$ Most studies focus on managerial incentives to manage earnings, and whether such management results in higher or lower accounting information quality. ${ }^{2}$ There is far less discussion of whether earnings management varies systematically with firm characteristics and/or the environment in which the firm operates. Evidence in Leuz et al. (2003) demonstrates that country-level factors, such as equity market development, investor rights, and legal enforcement are statistically significantly related to a country's median level of earnings management. These authors conjecture that managerial incentives interact with the legal and institutional environment to produce systematic differences across countries. We pursue this incentives-based explanation further by exploiting potentially important variation at the firm-level, such as whether the firm is controlled by a family or other large shareholder, or whether there is a direct connection to a politician. We find that these attributes do matter; indeed they remain statistically significant predictors of earnings quality even after country-level factors are controlled for in our regression analysis.

\footnotetext{
${ }^{1}$ Leuz and Oberholzer-Gee (2006) provide a hint into this direction by showing that Indonesian companies connected to president Suharto are less likely to cross-list their securities and thus to adopt U.S. GAAP.

${ }^{2}$ More generally, Hermalin and Weisbach (2007) argue that from a corporate governance perspective, activities that increase transparency may result in lower profits.
} 
Earnings management is often seen as a tool used by managers attempting to mislead, hide, or obscure information from shareholders or the public (e.g., Schipper, 1989, or Shivakumar, 2000). However, poor quality earnings may also result from other sources, e.g., inattention to detail on the part of the firm's mangers. Concerns about the quality of reported earnings may be especially salient for politically connected firms, since these firms typically derive gains from their connections ${ }^{3}$ over and above the payments they make. ${ }^{4}$ The nature of these payments and gains may create additional incentives to expropriate, or at least obscure information, from the firm's minority shareholders. Moreover, if politicians provide protection to their related companies, connected firms might care less about the quality of the information they disclose. That is, perhaps due to political pressures and intervention, connected companies do not face the same consequences (i.e., costs) of poor information quality as their non-connected peers. In either case, political connections will be associated with poor information quality.

Our evidence supports this view. In particular, we find that politically connected firms provide lower quality accounting earnings than do their non-connected peers. Moreover, we provide evidence that lower quality reported earnings is associated with higher cost of debt only for the non-politically connected firms in the sample. That is, companies that have political connections apparently face little negative consequences from their lower quality disclosures.

The empirical evidence we provide in this study is derived from two primary data bases. First, we employ a large firm-level data set on corporate political connections developed by Faccio (2006). Second, using underlying accounting data available in Worldscope, we construct a measure of accounting earnings quality based on the variability of discretionary accruals. As discussed above, we

\footnotetext{
${ }^{3}$ See, for example, Cull and Xu (2005), Johnson and Mitton (2003), and Khwaja and Mian (2005) for evidence of preferential access to credit; Backman (1999) and Dinç (2005) for evidence of preferential treatment by government owned banks; Agrawal and Knoeber (2001) for preferential treatment in the award of government contracts; and Faccio, Masulis and McConnell (2006) for bailouts.

${ }^{4}$ See Svensson (2003), Cull and Xu (2005), and Hellman, Jones and Kaufmann (2003) for a discussion of bribes, and Bertrand, Kramarz, Schoar, and Thesmar (2004), and Fan and Wong (2006) for vote-buying behavior. Bertrand et al. (2004) also discuss the employment consequences of connections and their impact on voting for politicians.
} 
also check whether the effects of political connections on accounting information quality depend on characteristics of a firm's ownership structure (e.g., the existence of large shareholders or family control).

The next section briefly describes how the political connections database was originally compiled. We then describe how we construct our proxy for accounting earnings quality. Sections 3 and 4 present our results and robustness tests. In section 5 we address the issue of endogeneity. We provide some justification for the reporting behavior of connected firms in section 6 . We offer our conclusions in section 7 .

\section{Political ties.}

A company is classified as politically connected if at least one of its large shareholders (anybody directly or indirectly controlling at least $10 \%$ of votes) or top directors (CEO, chairman of the board, president, vice-president, or secretary) is a member of parliament, a minister or a head of state, or is tightly related to a politician or party. These close relationships include cases of friendship, past top political (e.g., a head of state or minister) or corporate positions, as well as other ties identified in prior studies.

Connections with government ministers include cases in which the politician himself is a large shareholder or a top director, as well as cases where a politician's close relative (e.g., the son or daughter) holds such positions. Connections with a member of parliament, however, are recorded only when members of parliament themselves are shareholders or top directors, but do not consider cases when such positions are held by relatives. This was due to data limitations. Close relationships consist of cases of well-known friendship; share ownership or directorships held by former heads of state or prime ministers as well as former directorships held by current politicians, foreign politicians, and well documented relationships with political parties (Gomez and Jomo, 1997; and Johnson and Mitton, 2003). 
To establish the presence of connections, the names of top company directors were taken from Worldscope, Extel, company websites, and Lexis-Nexis, and the names of block-holders were identified from Claessens, Djankov, and Lang (2000), Faccio and Lang (2002), the web sites of the stock exchanges or their supervisory authorities, Worldscope, and Extel. The Chiefs of State directory (CIA, 2001) and the official website of the country's government and parliament were used to gather the names of members of parliament or government. In addition to these academic studies, The Economist, Forbes and Fortune are also used as primary sources of information for well-known cases of friendships.

For this study, we focus on countries with at least 5 politically connected companies in the Faccio (2006) database, which results in an initial sample of 21 countries and 17,435 companies. Since these connections are recorded between 1997 and 2001, and our analysis focuses on subsequent accounting information, endogeneity problems should be mitigated. We reconsider this issue in the robustness section. Matching this sample to those firms with the necessary accounting data ultimately reduces our sample as described below. The final sample of companies, including the number of connected companies, by country, is presented in Table 1, and is discussed in Section III below. We first describe our measure of earnings quality using data on accruals.

\section{The quality of accounting earnings data.}

Users of accounting information are often interested in assessing current performance as well estimating future performance, and there is considerable debate concerning how well various accounting measures reflect these goals. Some of the firm's transactions require only a mechanical application of accounting rules while other types rely on the judgment of the firm's managers and accountants. This judgment introduces errors - both intentional as well as unintentional. However, with respect to quality, the source of the error does not matter; both types reduce the quality of reported earnings. We follow other researchers in focusing on (the variability of) such errors estimated 
from a benchmark model of accounting accruals. Hence, a higher variance of unexplained accruals is associated with lower quality earnings data.

Reported earnings are considered a primary indicator of information quality (e.g., Dechow 1994, and Dechow et al. 1998). ${ }^{5}$ Because earnings, and cash from operations, differ by the amount of reported accruals, a standard practice is to focus on the magnitude and the variability of accruals to assess their quality, and thus indirectly the quality of reported earnings. In general, accruals include both discretionary and non-discretionary components. Below we describe our empirical approach to estimating these components.

Sloan (1996) finds that the accrual portion of earnings is less persistent than cash flows, implying that firms with high levels of accruals have lower quality earnings. Other studies suggest that managers affect the direction and magnitude of accruals, including Healy and Whalen (1999), and Dechow, et al. (1996), and Richardson, et al. (2003). Dechow et al. (1996), for example, find that 38 firms subject to SEC accounting and auditing enforcement release reported higher accruals than a control group, and Richardson, et al. (2003) document that firms reported higher accruals in periods preceding earnings restatements. However, given the inherent negative autocorrelation in accruals, opportunistic use will result in 'excessive' variability in earnings. ${ }^{6}$ Hence, most research has emphasized the variability of accruals, in particular of discretionary accruals (Francis et al. 2004, 2005).

We estimate a pooled time-series cross-sectional regression for country $j$ 's (non-discretionary) total current accruals as a function of the firm's change in sales $(\triangle$ Sales $)$, its gross investment in

\footnotetext{
5 Dechow (1994) reports that if stock returns are used as a measure of performance, earnings are more highly correlated with stock returns than are current period cash flows. In Dechow et al. (1998), earnings are shown to be a better proxy for future cash flows than current cash flows. Because of this, earnings are often used in firm valuation models as well as a measure of firm performance.

6 For example, suppose an economic event results in a firm recognizing sales in period t. However, the firm allows the customer to pay within 90 days. In this case, an accrual (accounts receivable) is created and will reverse in the future when the cash is collected.
} 
physical plant and equipment (GPPE), and industry and time dummies, using financial data from

Worldscope. $^{7}$

$$
\frac{\text { TCA }_{i j t}}{\text { Assets }_{i j t}}=\alpha_{j} \frac{\Delta \text { Sales }_{i j t}}{\text { Assets }_{i j t}}+\beta_{j} \frac{G P P E_{i j t}}{\text { Assets }_{i j t}}+\text { industry and year dummies }+\varepsilon_{i j t}
$$

where: $\Delta$ is the first difference (with respect to time) operator, and Total Current Accruals (TCA) equal,

$$
T C A_{i j t}=\Delta(\text { Current Assets })_{i j t}-\Delta(\text { Current Liabilities })_{i j t}-\Delta\left(\text { Cash }_{i j t}\right.
$$

$+\Delta(\text { Short term and Current long term Debt })_{i j t}$,

Current Assets (WC02201) is the sum of cash and equivalents, receivables, inventories, prepaid expenses and other current assets.

Current Liabilities (WC03101) represents debt or other obligations that the company expects to satisfy within one year.

Cash (WC02001) represents the sum of cash and short term investments.

Short Term and Current Long Term Debt (WC03051) represents that portion of financial debt payable within one year including current portion of long term debt and sinking fund requirements of preferred stock or debentures.

\footnotetext{
${ }^{7}$ As a robustness check, we estimate accruals using several different estimation techniques (including using Total Accruals instead of Total Current Accruals). One accruals estimate is computed following DeFond and Park (2001). In this approach, abnormal accruals are computed on a firm-level basis as the difference between realized working capital and an expectation of working capital based on the firm's prior period's historical relation between working capital to sales. A second approach used by McNichols (2002) includes lagged, concurrent, and future period's cash from operations in the estimated model for accruals (see Dechow and Dichev (2002)). Cash from operations is computed using the balance sheet approach. This second approach results in a smaller sample due to data restrictions. Using these measures of discretionary accruals, our results for both 5 and 10-year earnings quality measures are qualitatively unchanged.
} 
Assets (WC02999) are the sum of total current assets, long term receivables, investment in unconsolidated subsidiaries, other investments, net property plant and equipment and other assets,

Sales (WC01001) are defined as gross sales and other operating revenue less discounts returns and allowances, and,

$G P P E$ is the sum of net property, plant and equipment (WC02501) plus accumulated reserves for depreciation, depletion and amortization (WC02401).

The industry dummies are built based on Campbell's (1996) industry classification.

Equation (1) is estimated on a country-by-country basis including all firms with the requisite accounting data in any given year. The error term is the estimate of discretionary accruals. Accrual quality, for each firm $i$, is computed as the standard deviation of its residual $\left(\hat{\varepsilon}_{i j t}\right)$, using the most recent 10 years available in Worldscope. In cases with less than 10 years available, we require at least 9 annual observations (during 1985-2005). This allows us to compute our first accruals quality variable for a sample of 5,987 firms. We were then able to match 4,906 of these firms with those in the Faccio (2006) database of political connections described in Section I above. Since regression (1) produces an estimate of discretionary accruals, a higher residual standard deviation reflects lower quality reported earnings.

Since requiring 10 years of data may introduce some severe survivorship bias in our results, we re-compute a similar measure using only 5 years of data, which is available for 13,778 firms. ${ }^{8}$ In this case, data on political connections is available for 7,318 of these companies. Most of this difference is due to firms being added to Worldscope after 2001, i.e. after the political connections data base was compiled.

\footnotetext{
${ }^{8}$ Francis et al. (2004) and Francis et al. (2005), use 10-years, and 5-years of data respectively in estimating the standard deviation of accruals.
} 


\section{Descriptive statistics.}

Matching the accounting data from Worldscope with the data on political connections, and requiring that there be at least one connected firm in each country, our final sample (using the 5-year measure of accruals quality) includes 7,318 firms, 322 of which are connected to a politician, from 21 countries. Table 1 presents a number of summary statistics at the country level. The overall impression is that there is wide variation in the sample across all of the country-level measures tabulated.

[Table 1 goes about here]

For example, there is variation in both the number of firms and the number of connected firms per country. The countries range from poor (India and Indonesia) to rich (e.g., Canada, Denmark, and the United States), from high corruption (the Philippines, India, Indonesia, Russia) to low corruption (Denmark and Singapore). Finally, the average firm size (1997 U.S \$ market capitalization) varies widely, with relatively large firms sampled in Russia (only four firms included), France, Italy, Switzerland, and the United States. We describe the additional variables presented in Table 1 in more detail when we discuss the country specific control variables (in section III.b) below.

Given this cross-country variation, we take several precautions in our multivariate regression analysis. First, we report OLS estimates with standard errors adjusted for clustering at the country level. Moulton (1990) strikingly illustrates how clustering within a group biases estimated standard errors downward. The problem affects the standard errors on aggregate effects (e.g., corruption), on individual-specific response variables (e.g., earnings quality). In particular, since intra-group observations (in this case, a country) share common, perhaps unobservable, characteristics, a fundamental assumption (i.e., independence) of most estimation methods is violated. In addition to adjusting the standard errors for clustering, a natural concern is that this wide cross-country variation might increase the potential for extreme observations, especially for OLS estimation. This suggests an alternative estimation procedure might be better suited in our empirical setting. Hence, for robustness purposes, we also present estimates from a median regression framework, which minimizes the sum of 
the absolute value of residuals (see Koeneker and Hallock, 2001). Mostly, we find the results are robust to the inclusion/exclusion of outliers (we discuss the details in the robustness section below). Finally, we also repeated several of our benchmark specifications after eliminating entire countries, one at a time, from the analysis. Again, we find the results robust to this precaution.

\section{III.a. Univariate Analysis}

Table 2 presents the univariate associations of our two primary measures of accounting information quality vis-à-vis the specific connections variables, and firm ownership structures. In the first set of three columns we focus on the (10-year) standard deviation of discretionary accruals. Note that higher values of this variable indicate lower earnings quality. In the second set of three columns in the table we display the same information for the (5-year) standard deviation of discretionary accruals.

Each set of three rows present statistics by firm characteristic. For example, there are 205 connected firms for which we can compute the 10-year standard deviation, and its mean value for connected firms is 0.0646 , and is 0.0598 for other firms. The difference between these means is statistically significant at the $7 \%$ level.

Closely held firms, (e.g., family firms) may also be more inclined to establish political connections (Morck et al., 2000, Morck and Yeung, 2004). Hence, in an effort to insure that our political connections indicator is not mixing the effects of a firm's ownership structure and the effects of its connections on its reporting incentives, we introduce controls for family firms (Family), and for the size of the voting stake held by the largest ultimate shareholder (Control). The ownership and control data are taken from Claessens, Djankov, and Lang (2000), Faccio and Lang (2002), the web sites of the stock exchanges or their supervisory authorities, Worldscope, and Extel. The ownership related data are generally recorded as of the end of 1997. The difference in earnings quality between family and non-family firms is highly statistically significant (p-values $<0.001$ ), with family firms exhibiting a higher mean (lower quality earning) than non family firms. 
Connections can be divided into two sub-groups:

a) when a connection is tied to a government official (Gov), when a connection is tied to a minister of parliament $(M P)$, or when the connection is through a friendship or other indirect connection (Other). These categories are not strictly mutually exclusive, i.e., there are 4 observations in which $G o v=1$ and $O t h e r=1$, for the 10-year standard deviation of discretionary accruals measure of earnings quality, 5 observations in which Gov=1 and Other $=1$ and 1 observation in which $M P=1$ and Other $=1$, for the 5-year standard deviation of discretionary accruals measure of earnings quality.

b) when a connection is through a major shareholder (Own) or when the connection is through a director (Director). There is also a small overlap (of 11 observations) between these two measures for the 10-year measure, and 17 observations for the 5-year measure.

[Table 2 goes about here]

For specific connections we see that the strongest connections occur when they involve a high government official, or a close personal friendship, or when the connection is through a major shareholder (Faccio, 2006). Only when we focus on connections established at the director level are the differences in earnings quality statistically insignificant, and differences in earnings quality between firms with connections established through members of parliament versus non-connected companies are statistically significant (at the $7 \%$ level) only when we use the 10 -year measure. In general however, results are very similar for either the 5-, or 10-year measures of earnings quality. Overall, the analysis suggests that there are statistically significant differences in discretionary accruals for: connected and non-connected firms, and for family versus non-family firms. Of course, this univariate analysis cannot answer the questions which types of connections are most important, or whether the connections depend on country characteristics, such as the overall level of corruption within a country, or on other firm attributes, e.g., its size, market to book, or leverage. For these questions we turn to a multiple regression analysis. 


\section{III.b. Control variables}

Prior to reporting our regression results, we describe a number of firm and country characteristics that we use as controls in our multivariate analysis. Their inclusion is motivated by prior studies that have found them associated with the quality of accounting information at the firm or at the country level (Doidge, Karolyi, and Stulz, 2006, Fan and Wong, 2002, Leuz et al., 2003, Leuz, 2006).

We define Family as a dummy variable equal to 1 if the largest shareholder is a family or individual controlling at least $20 \%$ of the votes, and 0 otherwise. Control is constructed according to La Porta et al. (1999), who argue that an investor can gain control in a corporation by directly owning a controlling stake, or indirectly through holding shares in another corporation. In the first case, an investor's share of control rights will correspond to the fraction of votes he is entitled to express. In the second case, the investor's share of the control rights is measured by the weakest control link along the pyramid. We also allow for a non-linear impact of Control on accrual quality by including the squared value of this variable $\left(\mathrm{Control}^{2}\right)$ in some regression specifications.

Additional firm characteristics included in the regressions are computed from accounting data taken from Worldscope (with identifier), and measured for year 1997. ${ }^{9}$ First, the firm's size (LnMkCap), is measured as the natural log of the company's market capitalization (WC07210) in US dollars. We also control for the annual growth of sales during 1997 (SalGrwt), and standard deviation (SalGrwtSD) of sales (WC08631) during 1994-2005 (or the shorter period for which the data is available). Similarly, $M T B$ is defined as the ratio of market capitalization to book value of equity (MTBV), and Leverage is total debt as percentage of total assets (WC08236).

\footnotetext{
9 Fixing the independent variables as of 1997 makes the assumption of independence and exogeneity more plausible given that our dependent variable is measured over a 10 -year period ending in 2005 . We did however repeat all of the empirical analysis defining the independent variables as of 2005. None of our conclusions are affected by this choice.
} 
Finally, the country-level variables (Rights, and Corruption) are also included as separate controls. Rights is the interaction between the index of Anti-Director Rights (La Porta et al., 1998), and the index of Legal Enforcement. Anti-Director Rights is defined by La Porta et al. (1998), as: "The index is formed by adding 1 when (1) the country allows shareholders to mail their proxy vote to the firm, (2) shareholders are not required to deposit their shares prior to the general shareholders' meeting, (3) cumulative voting or proportional representation of minorities in the board of directors is allowed, (4) an oppressed minorities mechanism is in place, (5) the minimum percentage of share capital that entitles a shareholder to call for an extraordinary shareholders' meeting is less than or equal to 10 percent, or (6) shareholders have pre-emptive rights that can be waived only by a shareholders' vote." La Porta et al. (1998), Legal Enforcement is computed as the average across the degree of efficiency of the judicial system, an assessment of the rule of law, and corruption. Given these variables are highly correlated we use their interaction rather than entering these two variables separately. Conceptually, the interaction should capture the combined effect of legal quality and whether there is enforcement of those laws.

Our measure of Corruption within a country is taken from Transparency International ( www.transparency.org). The index measures the "degree to which corruption is perceived to exist among public officials and politicians. It is a composite index, drawing on 14 different polls and surveys from seven independent institutions, carried out among business people and country analysts, including surveys of residents, both local and expatriate." Corruption represents "the abuse of public office for private gain." Transparency International's index for 1997 is rescaled from 0 to 10, with higher values indicating higher corruption.

\section{III.c. Regression Analysis}

Table 3 presents OLS regressions in which the dependent variable is (see equation (1)), computed over a 10 year period (generally 1996-2005). The independent variables are measures of 
connections, ownership variables, and other company and country-level attributes. All regressions include industry dummies defined at the 4-digit SIC level. P-values, corrected for heteroskedasticity and clustering at the country level, are reported in parentheses below the coefficients estimates.

[Table 3 goes about here]

Regression (1) uses the all-inclusive measure of connections; we then partition these connections into individual types in regressions (4) and (5). In Regression (1), we find that connections are positively and significantly related to accruals quality (p-value $<0.04)$. The magnitude of the coefficient is economically large, and indicates that the presence of connections is associated with an $18 \%$ increase in the dependent variable $(1.0959 / 6.0029) .{ }^{10}$ Consistent with earlier studies, we find that the standard deviation of discretionary accruals is lower for larger companies; on the other hand, it increases with sales growth and the volatility of sales growth. We also find a higher standard deviation of discretionary accruals in high market-to-book firms, and a lower standard deviation of discretionary accruals in highly levered companies. Surprisingly, we find no correlation between accruals quality and the degree of corruption in a given country, or accruals quality and the quality of the legal system. This last result contrasts with earlier findings by Leuz et al. (2003). We are limited in the number of country-variables we can control for because of the relatively low number of countries in the study (21) and also because of the high correlation between several of the country variables. Our results are qualitatively unchanged after we control for industry fixed-effects (regression 2). To verify that our results are not driven by other country attributes, in Regression (3) we add country dummies (in place of the Rights and Corruption variables which are country specific). The previous results are robust to the new specification. The only major change is the increase in the explanatory power $\left(\mathrm{R}^{2}\right)$ of the regression model.

In Regressions (4) and (5) we partition connections into specific types. Previous studies (e.g., Faccio, 2006) have found that connections through the head of state or a government minister (either

\footnotetext{
${ }^{10} 6.0029$ is the sample average of the dependent variable.
} 
direct or through close relationships) are more valuable to firms than connections through a member of parliament. This likely reflects the larger benefits these firms receive and may need to "hide." Similarly, previous findings document a larger impact of connections through a block-holder, relative to connections through a director. Because of this, we expect companies with stronger connections to exhibit lower accounting quality. Our results support this expectation and we find that the coefficients on the stronger types of connections are always larger than those of weaker connections types.

In regressions (6) and (7) we add some governance variables. Fan and Wong (2002) find that closely held companies disclose less meaningful accounting information. To the extent that our measures of connectedness are correlated with ownership variables, we need to assess the robustness of our prior results to the inclusion of these additional controls. For our purposes, we start by controlling for the concentration of control (voting rights) in the hands of the largest shareholder. ${ }^{11}$ To better separate the alignment and entrenchment effects present at different levels of concentration of control, we also add the squared value of control in the model in regression (6). The results, however, indicate no statistical significance for this governance variable. Notice however, that connections remain significant. In regression (7) we isolate family firms. We find weak evidence that companies with a large family-block-holder use more discretion in reporting their accounting numbers, in that the coefficient of family firms is positive but not significant at conventional levels ( $p$-value $=0.116$ ).

To better control for the presence of outliers, we re-estimate the first regression using a median regression framework, which minimizes the sum of the absolute value of residuals (see Koeneker and Hallock, 2001). In these regressions, extreme observations are given less weight in the regression (the regression minimizes the absolute residuals rather than the squared residuals). In the regressions, standard errors are computed using bootstrap resampling, with 100 bootstrap replications, to control for heteroskedasticity (see Efron and Tibshirani, 1993, and Wu, 1986). Regression (8) reports these robustness results. These results indicate that outliers are not a problem: the coefficient of

\footnotetext{
${ }^{11}$ As the ownership data is available only for a sub-sample of the companies/countries in our dataset, we end up with a much smaller sample size in Regressions (5)-(7).
} 
connections in fact changes very little when we use a median regression approach. If anything, the significance of our previous results is increased. ${ }^{12}$

As noted above, using 10 years of data to compute our dependent variable (as in Table 3) potentially introduces a survivorship bias. To address this issue, we repeat the analysis using the standard deviation of residuals of the most recent 5 years (2001-2005) of data. In addition to reducing survivorship bias concerns, this measure has an added advantage. Namely, in this specification, the contemporaneous link between political connections and earnings quality is severed since the political connections dataset employed is based on a prior time period (i.e., between 1997 and 2001). ${ }^{13}$ So, it is clear that now our measure of connectedness precedes the period over which we assess the quality of earnings. We believe this leads to a stronger interpretation of our results. The new results are reported in Table 4. We continue to adjust standard errors for heteroskedasticity and clustering.

[Table 4 goes about here]

All the results on political connections are supported when we use the shorter period to measure earnings quality. Regression (1) shows that being connected results in a 19\% (1.0899/5.7547) increase in the dependent variable (e.g., thus results in lower earnings quality). This result is significant at the 5\% level. The positive relation between connections and our new measure of accruals quality is supported when we add industry dummies to the model, or control for the ownership structure of the company (regressions 6 and 7). Once again, when we partition connections by type, we continue to find a larger effect for connections with the head of state or government minister (both direct, and those through a close relationship) rather than connections with a simple member of parliament. Similarly, connections through the owner are associated with a higher standard deviation

12 An additional concern, partly addressed by removing outliers, is the impact of mergers. Potentially, mergers could artificially induce variability in the dependent variable, thus leading us to categorize these firms as those with poor accounting information. Recent evidence in Ashbaugh-Skaife, Collins, Kinney, and LaFond (2006) however suggests that neither mergers nor restructurings have a statistically significant impact on measures of earnings quality, at least in the United States.

${ }^{13}$ Of course, this also has disadvantages, such as the new measure is more sensitive to outliers or temporary shocks. 
in the amount of discretionary accruals than connections through a director. The impact of the ownership structure of our sample firms continues to remain marginal. On the other hand, the previous results on the other control variables are generally supported. With accruals quality measured using 5years of data we lose significance for the connections variable in the specification that includes both industry and country dummies to the regression. However, in regression (8) we use a median regression approach to control for the impact of outliers, and connections remain highly significant (pvalue $<0.01)$

\section{Robustness tests.}

\section{IV.a. Exclusion of individual countries}

To provide assurances that our results are not driven by any specific country, we recursively repeat our estimations, omitting a single country each iteration. When the 10-year standard deviation of the discretionary accruals measure is used as dependent variable, the coefficients on connections are always positive, ranging from 0.8409 to 1.3308 , and statistically significant (p-values range between 0.001 and 0.032 ). When the 5-year measure is employed, the coefficients on connections range from 0.4356 to 1.117 . The coefficient is significant in 19 out of 21 regressions; only when we exclude Japan or Malaysia, does the coefficient lose statistical significance.

\section{IV.b. Transformations of the dependent variable and alternative estimation methods}

By construction, the dependent variable in our regression models is positive. Because of this truncation, the disturbance terms may not be normally distributed. A possible solution to this problem is to use a logistic transformation, where the new dependent variable is computed as:

$z_{i}=\log \left(\frac{\frac{y_{i}}{\max \left(y_{i}\right)+\theta}}{1-\frac{y_{i}}{\max \left(y_{i}\right)+\theta}}\right)=\alpha_{0}+\alpha_{1} \operatorname{Conn}_{\mathrm{i}}+\sum_{k=1}^{n} \alpha_{k} \operatorname{Controls}_{\mathrm{k}, \mathrm{i}}+\varepsilon_{\mathrm{i}} \quad \mathrm{i}=1,2, \ldots, \mathrm{n} ; \theta>0$ 
In this case $z_{i}$ satisfies $-\infty<z_{i}<\infty$, and thus the truncation problem is avoided. We can therefore employ this specification to assess the robustness of our previous results in Table 3. For space reasons, these robustness results are not tabulated. When we assume $\theta=0.0001$, and re-run the regressions, we find that the coefficient of Connected ranges between 0.135 and 0.252 , while the pvalues of this coefficient range from 0.007 to 0.028 . We then allow $\theta$ to assume larger values (e.g., $0.01,1$, or 10) and find similar levels of significance.

As a second approach to this issue, we use the following inverse integral transformation to arrive at a new measure of accruals quality which is distributed as a standard normal variable. First let $Q_{i}$ be our accruals quality measure described above, i.e., $Q_{i}=\sqrt{\frac{1}{T-1} \sum_{t=1}^{T}\left(\hat{\varepsilon}_{i t}-\hat{\bar{\varepsilon}}_{i}\right)^{2}}$, for firms $i=1, \ldots, M$ is computed as the standard deviation of residuals $\left(\hat{\varepsilon}_{i t}\right)$ estimated from equation (1), using the most recent $T$ years of data. If the residuals, $\hat{\varepsilon}_{i 1}, \ldots . ., \hat{\varepsilon}_{i T}$, are $i i d$ normal random observations ${ }^{14}$ with mean $\mu=0$ and variance $\sigma^{2}$, then $U_{i}=\frac{(T-1) Q_{i}^{2}}{\sigma^{2}} \sim \chi_{(T-1)}^{2}$. Since $\mu$ is known, we can estimate $\sigma^{2}$ with $\frac{1}{M T} \sum_{i=1}^{M} \sum_{t=1}^{T}\left(\hat{\varepsilon}_{i t}\right)^{2} \cdot{ }^{15}$ Using the $\chi^{2}$ cumulative density function, $F(U)=\int_{0}^{U_{i}} f(\delta) d \delta$, we transform the $U_{i}$ 's to probabilities, i.e., $F(U) \sim U[0,1]$. Finally, we use the inverted standard normal distribution, $\Phi^{-1}(F(U))$, to transform these probabilities, $F(U)$, into a new measure of accruals quality, $Q_{i}^{*}$, which are distributed $N(0,1)$. With these assumptions in mind, we transform our dependent variable using the procedure described, and re-run the regressions reported in Table 3. We now find that the coefficient of Connected ranges between 0.417 and 0.738 . Its p-value is always significant, ranging from 0.006 to 0.058 .

${ }^{14}$ It is important that the residuals are identically distributed. Otherwise we would need to define $U_{i}=\frac{(T-1) Q_{i}^{2}}{\sigma_{i}^{2}} \sim \chi_{(T-1)}^{2}$, and estimate $\sigma_{i}^{2}$ with $\frac{1}{T} \sum_{t=1}^{T}\left(\hat{\varepsilon}_{i t}\right)^{2}$

${ }^{15}$ The formula for the estimate of $\sigma^{2}$ is not strictly correct since there may be a different $T$ for each firm $i$. 
Finally, we re-run our specifications alternatively employing a Tobit estimation model, and using the log of our accruals quality measure as the dependent variable. Though not reported to conserve space, all our results are unchanged.

\section{IV.c. Alternative measures of earnings quality.}

As a robustness check, we estimate accruals using several different ways (including using Total Accruals instead of Total Current Accruals). One accruals estimate is computed following DeFond and Park (2001). In this approach, firm-level abnormal accruals are computed as the difference between realized working capital and an expectation of working capital based on the firm's prior period's historical relation between working capital and sales. A second approach used by McNichols (2002) includes lagged, concurrent, and future period's cash from operations in the estimated model for accruals (see Dechow and Dichev (2002)). Cash from operations is computed using the balance sheet approach. This second approach results in a smaller sample due to data restrictions. Using these measures of discretionary accruals, our results for both 5 and 10-year earnings quality measures are qualitatively unchanged.

Additionally, we employ income smoothness, measured as the firm's standard deviation of cash from operations relative to the standard deviation of income before extraordinary items (e.g., Leuz et al. 2003). Income smoothness is often considered another attribute of earnings quality. Our results generally show that connected firms have less smooth earnings. This general result is robust to controlling for the ownership characteristics of connected firms. Additionally, this result is stronger for connections with a member of the cabinet. Interestingly, when using smoothness as the dependent variable, we find strong significance for the ownership variables. In particular, we find that a higher concentration of control rights or a family blockbolder results in less smooth earnings. 


\section{Endogeneity.}

One potential concern for the estimates reported so far is that the decision to form connections may not be exogenous. In fact there may be reciprocal causation, leading our reported OLS estimates to be biased and inconsistent. This issue was partly addressed in Table 4, when we considered connections formed prior to our measure of accruals quality; however, in this section we describe results obtained from an instrumental variables estimation. Our choice of instrument is motivated by previous studies finding strong localized effects of political connections (e.g. Roberts 1990, Agrawal, and Knoeber, 2001). In the first stage regression, we predict (via a probit estimation) connections using the location of the company's headquarters, as well as the other independent variables included in previous regressions. Specifically, Capital is a dummy variable that takes the value 1 if the company is headquartered in the capital of its country and 0 otherwise. The first-stage fitted values for connected (I_Connected) are then used in the second stage OLS regressions. ${ }^{16}$

[Table 5 goes about here]

Table 5 reports results for each of the two measures of earnings quality discussed in Tables 3 and 4. For each dependent variable we report both the first- and second-stage results. In all specifications the presence of a firm's headquarters in the capital city is a (highly) statistically significant predictor of whether the firm establishes a political connection. Moreover, in each of the second stage regressions, the instrumented value of connections is statistically significant as well. In all cases the estimated coefficient is larger than those reported using OLS, and they remain highly statistically significant. Other results are also similar. For example, the standard deviation of discretionary accruals is smaller for large firms. The only difference from the previous results is that we now find that firms in more corrupt societies have lower discretionary accruals, while firms headquartered in countries with better legal systems tend to have poorer quality accruals. We

\footnotetext{
${ }^{16}$ Econometrically, we implement this using the STATA command cdsimeq, which corrects the standard errors for the fact that the first-stage regression is a probit estimation.
} 
recognize that the significance of the country variables in this IV approach may be overstated given that we cannot properly control for clustering.

\section{Why don't connected firms care about the consequences of poor earnings quality?}

We have shown that, on average, the accruals quality of connected companies is poorer than the quality of accruals of non-connected firms. From an empirical standpoint, a number of studies have shown that poor accrual quality results in a number of negative consequences at the firm level, including a higher cost of capital, or a higher likelihood of a lawsuit. Thus the question becomes why connected firms appear not to care about the consequences. One possibility is that their political ties allow mitigating or even eliminating such effects. So, for example, it might be possible that lenders of connected firms provide them with relatively cheap capital, regardless to the opacity/quality of their accounting information.

To address this question in detail, we focus on the cost of debt. This choice is driven by the fact that the overwhelming majority of studies on political ties document preferential access to credit for connected firms (Cull and Xu, 2005, Dinç, 2005, Johnson and Mitton, 2003, Khwaja and Mian, 2005). Thus, perhaps due to political pressure on (government owned) banks, despite their poor accruals quality, connected firms are able to avoid paying higher interest rates. If that were the case, this would provide a justification as to why connected firms exhibit significantly poorer accruals quality despite the negative consequences generally associated with poor quality.

In our analysis, we follow Francis et al. (2005), and compute the cost of debt as the ratio of a firm's interest expense in year t (in our case 2005) (WC01251) over the average interest bearing obligations outstanding as of the end of year t-1 and $\mathrm{t}$ (WC03255). This gives us the realized cost of debt in the company's local currency. To make these rates comparable across countries, we convert them in U.S. dollar terms using the covered interest parity. Thus, given a cost of borrowing in the local currency of $i_{L C}$, we define the dollar cost (i $\left.i_{U S}\right)$ of borrowing local currency, 
$i_{U S}=i_{L C} \cdot\left[1+\frac{e_{1}-e_{0}}{e_{0}}\right]+\frac{e_{1}-e_{0}}{e_{0}}$, where $e_{0}$ and $e_{1}$ are the spot and the one year forward rates as of the beginning of $2005(\mathrm{e}=\mathrm{LC} / \$)$. Table 6 reports the univariate results. Generally, we find that the cost of debt is higher for companies with poorer accruals. This tends to be true both for connected and nonconnected firms. However, there seem to be a larger premium applied to non-connected firms that report poor accounting information. Once again, it is necessary to evaluate whether the results stand in a multivariate framework.

[Table 6 goes about here]

As standard in the literature, our regressions control for a number of factors that are known to influence interest rates: leverage, size, cash flow volatility, return on assets, and the interest coverage ratio. Leverage is total debt as percentage of total assets (WC08236) as of year end $\mathrm{t}-1$; size (LnMkCap), is measured as the natural log of the company's market capitalization (WC07210) in US dollars, as of year end t-1; volatility is the standard deviation (SalGrwtSD) of sales growth during 1994-2005 (or the shorter period for which the data is available). We define Return on Assets (WC08326) as operating income (after taxes) to total assets in year t-1; the Interest Coverage Ratio is the ratio of operating income (WC01250) to interest expense (WC01251) in year t-1. Because of the presence of outliers, we exclude companies with a cost of debt in the top/bottom percentile, as well as companies with an interest coverage ratio in the top/bottom percentile.

We run separate regressions for connected and non-connected firms. Similarly, separate regressions are run for each of our earnings quality measures. The results are reported in Table 7 . We find that, for non-connected firms, lower accruals quality (higher standard deviation of accruals, results in a significantly higher cost of debt (regressions 1, and 3). The cost of debt is negatively related to sales growth volatility, and leverage. These results are perhaps surprising. However, Francis et al. (2005) also find a negative relation between leverage and the cost of debt. The offered the explanation that this may be driven by companies who chose not to lever because of the particularly 
high cost of debt they face. Another possibility is that some companies may repay their debt immediately before the end of the year in order to hide their financial position to the market; for these companies we would end up inferring high interest rates because of the procedure used to compute the cost of debt. In general, we do not find a relation between profitability (ROA) or the likelihood of bankruptcy (as proxied by the interest coverage ratio), and the cost of debt.

The results with respect to our control variables hold for the sample of connected firms (regressions 2, and 4). However, for connected firms we fail to find any relationship between earnings quality and the cost of debt. Moreover, the difference between the coefficient of Stresid (10 yrs) in regressions (1) and (2) (non-connected vs connected) is significant with a p-value of 0.008 ; the difference between the coefficient of Stresid (5 yrs) in regressions (3) and (4) (non-connected vs connected) is significant with a p-value of less than $0.001 .^{17}$ This indicates that, despite their poor accruals quality, connected firms are not penalized by their lenders, which in turn, may be due to political pressures faced by lenders, especially in the case of government owned banks. From our perspective this result explains why connected firms do not appear to care about the quality of their earnings, in that there is no penalty applied to those firms that report lower quality information.

[Table 7 goes about here]

\section{Conclusions.}

This study documents that the quality of reported accounting information is systematically poorer for firms with political connections than for firms lacking such connections. This conclusion is based on an analysis of accounting data from more than 7,000 firms in 21 countries. Political connections appear to be a more important predictor of accounting quality than several commonly used country level variables such as the overall level of corruption, the quality of the legal system, or

\footnotetext{
${ }^{17}$ For non-connected firms, the economic impact of poor earnings quality is particularly large. A one standard deviation increase in the $10(5)$ year measure of accruals quality results in a $92(85)$ basis points increase in the cost of debt.
} 
shareholder rights indicators. Indeed, after controlling for firm-specific factors (political connections, ownership structure, size, growth, leverage, market-to-book ratios), country-level factors are rarely statistically significant in our regressions. Moreover, connections occurring through a block-holder, and to politicians higher in the government have even stronger effects.

Previous research has found that there are costs associated with lower quality accounting information, and our results are consistent with this finding, but with a twist. In particular, we provide evidence that lower quality reported earnings is associated with higher cost of debt only for the nonpolitically connected firms in the sample. That is, companies that have political connections apparently face little negative consequences from their lower quality disclosures.

To check the robustness of these results we have considered alternative measures of earnings quality, as well as performing the estimations using several different approaches (including OLS, IV, tobit, median regressions, re-computing our dependent variables using a logistic transformation, an inverse integral transformation, and taking logs. We have also re-run the regressions eliminating outliers, and countries one at a time). The results are robust to these alternative specifications. 


\section{References}

Agrawal, Anup, and Charles R. Knoeber, 2001, "Do some outside directors play a political role?" Journal of Law and Economics, 44: 179-198.

Ashbaugh-Skaife, Hollis, Daniel W. Collins, William R. Kinney, Jr., and Ryan LaFond, 2006, "The Effect of Internal Control Deficiencies and Their Remedian on Accrual Quality," working paper, University of Iowa.

Backman, Michael, 1999, “Asian eclipse: Exposing the dark side of business in Asia," Wiley: Singapore.

Bertrand, Marianne, Francis Kramarz, Antoinette Schoar, and David Thesmar, 2004, "Politically connected CEOs and corporate outcomes: Evidence from France," working paper, University of Chicago.

Campbell, John, 1996, “Understanding risk and return,” Journal of Political Economy, 104: 298-345.

Chan, Konan, Louis K. C. Chan, Narasimhan Jegadeesh, and Josef Lakonishok, 2006 "Earnings quality and stock returns," Journal of Business, 79: 1041-1082.

Claessens, Stijn, Simeon Djankov, and Larry H. P. Lang, 2000, “The separation of ownership and control in East Asian corporations," Journal of Financial Economics, 58: 81-112.

Cull, Robert, and Lixin Colin $\mathrm{Xu}, 2005$, "Institutions, ownership and finance: The determinants of profit reinvestment among Chinese firms," Journal of Financial Economics, 77: 117-146.

Dechow, Patricia M., 1994, "Accounting earnings and cash flows as measures of firm performance: the role of accruals," Journal of Accounting and Economics, 18: 3-42.

Dechow, Patricia M., Richard G. Sloan, and A. P. Sweeney, 1995, "Detecting earnings management," The Accounting Review, 70: 193-225

Dechow, Patricia, Richard Sloan and Amy Sweeney, 1996, "Causes and Consequences of Earnings Manipulation: An Analysis of Firms Subject to Enforcement Actions by the SEC," Contemporary Accounting Research, 1-36.

Dechow, Patricia M., S. P. Kothari, and R. L. Watts, 1998, "The relation between earnings and cash flows," Journal of Accounting and Economics, 25: 133-168

Dechow, Patricia M. and Ilia D. Dichev, 2002, "The quality of accruals and earnings: The role of accrual estimation errors," The Accounting Review, 77: 35-59.

DeFond, Mark. L. and Chul W. Park, 2001, "The reversal of abnormal accruals and the market valuation of earnings surprises," The Accounting Review, 76: 375-404.

Dinç, I. Serdar, 2005, "Politicians and banks: political influences on government-owned banks in emerging countries," Journal of Financial Economics, 77: 453-479.

Doidge, Craig, G. Andrew Karolyi, and René M. Stulz, 2006, "Why do countries matter so much for corporate governance?” working paper, Ohio State University.

Efron, Bradley and Robert J. Tibshirani, 1993, “An introduction to the bootstrap," New York: Chapman \& Hall.

Faccio, Mara, 2006, "Politically connected firms, ” American Economic Review, 96: 369-386.

Faccio, Mara, and Larry H. P. Lang, 2002, "The ultimate ownership of western European corporations," Journal of Financial Economics, 65: 365-395. 
Faccio, Mara, Ronald W. Masulis, and John J. McConnell, 2006, "Political connections and corporate bailouts", Journal of Finance, forthcoming.

Fan, Joseph, and T.J. Wong, 2002, "Corporate ownership structure and the informativeness of accounting earnings in East Asia," Journal of Accounting and Economics, 33: 401-425.

Fan, Joseph, and T.J. Wong, 2006, "Politically-connected CEOs, corporate governance and post-IPO performance of China's partially privatized firms," Journal of Financial Economics, forthcoming.

Francis, Jennifer, D. Philbrick, and K. Schipper, 1994, "Shareholder litigation and corporate disclosures," Journal of Accounting Research 32, 137-164.

Francis, Jennifer, Ryan LaFond, Per Olsson, and Katherine Schipper, 2004, "Cost of equity and earnings attributes," The Accounting Review, 79: 967-1010.

Francis, Jennifer, Ryan LaFond, Per Olsson, and Katherine Schipper, 2005, "The market pricing of accruals quality," Journal of Accounting and Economics, 39: 295-327.

Gomez, Edmund Terence, and K.S. Jomo, 1997, “Malaysia's political economy: Politics, patronage and profits, " Cambridge University Press: Cambridge

Healy, P. M. and J. M. Wahlen, 1999, "A review of earnings management literature and its implications for standard setting," Accounting Horizons, 13: 365-383.

Hellman, Joel S., Geraint Jones, and Daniel Kaufmann, 2003, "Seize the State, seize the day. State capture, corruption, and influence in transition," Journal of Comparative Economics, 31: 751773.

Hermalin, Benjamin E., and Michael S. Weisbach, 2007, "Transparency and Corporate Governance," working paper, University of Illinois.

Johnson, Simon, and Todd Mitton, 2003, "Cronyism and capital controls: Evidence from Malaysia," Journal of Financial Economics, 67: 351-382.

Keshk, Omar M.G., 2003, “CDSIMEQ: A program to implement two-stage probit least squares,” The Stata Journal, 3: 1-11.

Khwaja, Asim Ijaz, and Atif Mian, 2005, "Do lenders favor politically connected firms? Rent-seeking in an emerging financial market," Quarterly Journal of Economics, 120: 1371-1411.

Koeneker, Roger, and Kevin F. Hallock, 2001, "Quantile regression", Journal of Economic Perspectives, 15: 143-156.

La Porta, Rafael, Florencio Lopez-de-Silanes, Andrei Shleifer, and Robert W. Vishny, 1998, "Law and finance," Journal of Political Economy, 106: 1113-1155.

La Porta, R., Lopez-de-Silanes, F., Shleifer, A., 1999, "Corporate ownership around the world," Journal of Finance, 54: 471-518.

Leuz, Christian, 2006, "Cross listing, bonding and firms' reporting incentives: A discussion of Lang, Ready and Wilson (2006)," Journal of Accounting and Economics, 42: 285-299.

Leuz, Christian, and Felix Oberholzer-Gee, 2006, "Political relationships, global financing, and corporate transparency: Evidence from Indonesia," Journal of Financial Economics, 81: 411439.

Leuz, Christian, Dhananjay Nanda, and Peter D. Wysocki, 2003, "Earnings management and investor protection: an international comparison," Journal of Financial Economics, 69: 505-527. 
Maddala, G.S., 1983, “Limited-Dependent and Qualitative Variables in Econometrics," Cambridge, MA: Cambridge University Press.

McNichols, Maureen F., 2002, "Discussion of the quality of accruals and earnings: The role of accrual estimation errors," The Accounting Review, 77: 61-69.

Morck, Randall K., David A. Stangeland, and Bernard Yeung, 2000, "Inherited wealth, corporate control, and economic growth: The Canadian disease." In: R. Morck (ed.), "Concentrated corporate ownership", University of Chicago Press: Chicago.

Morck, Randall K., and Bernard Yeung, 2004, "Family control and the rent-seeking society," Entrepreneurship: Theory and Practice, 28: 391-409.

Moulton, Brent R., 1990, “An illustration of a pitfall in estimating the effects of aggregate variables on micro units", The Review of Economics and Statistics, 72: 334-338.

Richardson, Scott, Patricia Dechow, and İrem Tuna, 2003, "Why are Earnings Kinky?: An examination of the earnings management explanation," Review of Accounting Studies, 8, 355384.

Roberts, Brian E., 1990, "A dead senator tells no lies: Seniority and the distribution of federal benefits," American Journal of Political Science, 34: 31-58.

Shipper, K. 1989, "Commentary on earnings management," Accounting Horizons, 3: 91-102

Shivakumar, Lakshmanan, 2000, "Do firms mislead investors by overstating earnings before seasoned equity offerings", Journal of Accounting and Economics 29 (3), 339-371.

Sloan, Richard G., 1996, "Do stock prices fully reflect information in accruals and cash flows about future earnings?" The Accounting Review, 71: 289-315.

Svensson, Jakob, 2003, "Who must pay bribes and how much? Evidence from a cross-section of firms," Quarterly Journal of Economics, 118: 207-230.

Wu, Chien-Fu Jeff, 1986, "Jackknife, bootstrap and other resampling methods in regression analysis," Annals of Statistics, 14:1261-1350. 
Table 1. Countries, firms, and, connected firms included in the sample.

The sample of firms was defined by two steps. In step 1, countries with more than 5 connected companies were selected from data provided by Faccio (2006). In step 2, we also require these firms to have a minimum of 9 consecutive years of accounting information available in Worldscope that allows us to compute our earnings quality measures. Accounting Standards, Anti-Director Rights, and Legal Enforcement are taken from La Porta et al. (1998) ( http://post.economics.harvard.edu/faculty/shleifer/Data/l\&fweb.xls). Corruption Index is from Transparency International. Growth Volatility is defined as the standard deviation of the annual growth in real GDP (in domestic currency). Inflation volatility is defined as the standard deviation of annual inflation over the period 1985-2005. In cases where fewer observations are available, we compute the standard deviation over the longest period for which a country has data. Per Capita income is defined for 2005, on a Purchasing Power Parity basis, and expressed in U.S. dollars. The source for inflation, real GDP, and Per Capita Income is the World Economic Outlook Data base from the IMF, available at: http://www.imf.org/external/ns/cs.aspx?id=28.

\begin{tabular}{|c|c|c|c|c|c|c|}
\hline \multicolumn{2}{|c|}{$\begin{array}{l}\text { Panel A: } \\
\quad \text { Countries }\end{array}$} & $\begin{array}{l}\text { Number of } \\
\text { Companies }\end{array}$ & $\begin{array}{c}\text { Number } \\
\text { Connected }\end{array}$ & $\begin{array}{l}\text { Corruption } \\
\text { Index }\end{array}$ & $\begin{array}{l}\text { Accounting } \\
\text { Standards }\end{array}$ & $\begin{array}{l}\text { Anti-Director } \\
\text { Rights }\end{array}$ \\
\hline 1 & Belgium & 44 & 3 & 2.5 & 61 & 0 \\
\hline 2 & Canada & 246 & 2 & 1.5 & 74 & 5 \\
\hline 3 & Denmark & 89 & 3 & 0.5 & 62 & 2 \\
\hline 4 & France & 301 & 14 & 2.9 & 69 & 3 \\
\hline 5 & Germany & 323 & 9 & 1.8 & 62 & 1 \\
\hline 6 & Hong Kong & 245 & 3 & 2.0 & 69 & 5 \\
\hline 7 & India & 201 & 7 & 7.2 & 57 & 5 \\
\hline 8 & Indonesia & 93 & 25 & 8.0 & NA & 2 \\
\hline 9 & Italy & 93 & 10 & 5.2 & 62 & 1 \\
\hline 10 & Japan & 1806 & 27 & 3.1 & 65 & 4 \\
\hline 11 & Malaysia & 298 & 62 & 5.0 & 76 & 4 \\
\hline 12 & Mexico & 54 & 8 & 6.4 & 60 & 1 \\
\hline 13 & Philippines & 62 & 3 & 7.4 & 65 & 3 \\
\hline 14 & Russia & 3 & 2 & 7.2 & NA & NA \\
\hline 15 & Singapore & 149 & 10 & 0.7 & 78 & 4 \\
\hline 16 & South Korea & 187 & 7 & 5.5 & 62 & 2 \\
\hline 17 & Switzerland & 115 & 4 & 0.9 & 68 & 2 \\
\hline 18 & Taiwan & 195 & 4 & 4.4 & 65 & 3 \\
\hline 19 & Thailand & 150 & 18 & 6.4 & 64 & 2 \\
\hline 20 & UK & 732 & 85 & 1.4 & 78 & 5 \\
\hline 21 & US & 1932 & 16 & 2.5 & 71 & 5 \\
\hline \multicolumn{2}{|c|}{$\begin{array}{l}\text { Panel B: } \\
\text { Countries }\end{array}$} & $\begin{array}{c}\text { Legal } \\
\text { Enforcement }\end{array}$ & $\begin{array}{l}\text { Growth } \\
\text { Volatility }\end{array}$ & $\begin{array}{l}\text { Inflation } \\
\text { Volatility }\end{array}$ & $\begin{array}{c}\text { Per Capita } \\
\text { Income (US\$) }\end{array}$ & $\begin{array}{l}\text { Average (US\$) } \\
\text { Market Cap }\end{array}$ \\
\hline 1 & Belgium & 9.4 & 0.01 & 0.98 & 31,244 & $1,147,102$ \\
\hline 2 & Canada & 9.8 & 0.02 & 1.46 & 34,273 & $1,194,607$ \\
\hline 3 & Denmark & 10 & 0.02 & 1.07 & 34,740 & 765,399 \\
\hline 4 & France & 8.7 & 0.01 & 1.12 & 29,187 & $1,613,997$ \\
\hline 5 & Germany & 9.1 & 0.02 & 1.28 & 30,579 & $1,624,611$ \\
\hline 6 & Hong Kong & 8.9 & 0.04 & 5.17 & 33,479 & 806,830 \\
\hline 7 & India & 5.6 & 0.02 & 3.26 & 3,320 & 419,042 \\
\hline 8 & Indonesia & 2.9 & 0.05 & 11.34 & 4,459 & 272,777 \\
\hline 9 & Italy & 7.1 & 0.01 & 1.97 & 28,534 & $2,209,631$ \\
\hline 10 & Japan & 9.2 & 0.02 & 1.24 & 30,615 & $1,170,736$ \\
\hline 11 & Malaysia & 7.7 & 0.04 & 1.40 & 11,201 & 426,697 \\
\hline 12 & Mexico & 5.4 & 0.03 & 36.57 & 10,186 & 219,287 \\
\hline 13 & Philippines & 3.5 & 0.02 & 5.32 & 4,923 & 275,114 \\
\hline 14 & Russia & NA & 0.07 & 242.80 & 11,041 & $11,904,822$ \\
\hline 15 & Singapore & 8.9 & 0.04 & 1.29 & 28,368 & 522,435 \\
\hline 16 & South Korea & 5.6 & 0.04 & 2.22 & 20,590 & 135,558 \\
\hline 17 & Switzerland & 10 & 0.01 & 1.66 & 32,571 & $3,035,693$ \\
\hline 18 & Taiwan & 7.4 & 0.03 & 1.69 & 27,721 & 884,693 \\
\hline 19 & Thailand & 4.9 & 0.05 & 2.09 & 8,368 & 111,174 \\
\hline 20 & UK & 9.2 & 0.01 & 1.95 & 30,436 & $1,414,390$ \\
\hline 21 & US & 9.5 & 0.01 & 1.01 & 41,399 & $2,739,813$ \\
\hline
\end{tabular}




\section{Table 2. Accounting Information Quality and Political Connections: Univariate Statistics.}

The measures of accounting information quality are the standard deviation (computed using the most recent 5-, or 10-years) of the firm's discretionary accruals (estimated from equation 1 in the text). Connected is a dummy variable set equal to 1 if the company is connected to a politician and 0 otherwise. A company is classified as politically connected if at least one of its large shareholders (anybody directly or indirectly controlling at least $10 \%$ of votes) or top directors (CEO, chairman of the board, president, vice-president, or secretary) is a member of parliament, a minister or a head of state, or is tightly related to a politician or party. For specific types of political connections, Gov takes the value 1 when the firm's connection is with a government official; $M P$ takes the value 1 when the firm's connection is with a member of parliament; Other takes the value 1 when the connection is a friendship or other indirect connection; Own takes the value 1 when the connection is through a major shareholder; Director takes the value 1 when the connection is through a director of the firm. Family is a dummy variable set equal to 1 if the largest shareholder is a family or individual who controls at least $20 \%$ of the votes and 0 otherwise.

\begin{tabular}{|c|c|c|c|c|}
\hline & \multicolumn{2}{|c|}{$\begin{array}{l}\text { 10-year standard deviation of } \\
\text { Discretionary accruals }\end{array}$} & \multicolumn{2}{|c|}{$\begin{array}{c}\text { 5-year standard deviation of } \\
\text { Discretionary accruals }\end{array}$} \\
\hline & N. of Obs. & Mean & N. of Obs. & Mean \\
\hline Connected $=1$ & 205 & 0.0646 & 322 & 0.0649 \\
\hline Connected $=0$ & 4,701 & 0.0598 & 6,996 & 0.0572 \\
\hline Difference (p-value) & & $(0.073)$ & & $(0.002)$ \\
\hline Family = 1 & 933 & 0.0676 & 1,445 & 0.0659 \\
\hline Family $=0$ & 1,348 & 0.0524 & 2,075 & 0.0523 \\
\hline Difference (p-value) & & $(0.000)$ & & $(0.000)$ \\
\hline \multicolumn{5}{|c|}{ Specific types of political connections: } \\
\hline Gov $=1$ & 32 & 0.0845 & 48 & 0.0785 \\
\hline Gov $=0$ & 4,874 & 0.0599 & 7,270 & 0.0574 \\
\hline Difference (p-value) & & $(0.000)$ & & $(0.001)$ \\
\hline $\mathrm{MP}=1$ & 112 & 0.0538 & 182 & 0.0558 \\
\hline $\mathrm{MP}=0$ & 4,794 & 0.0602 & 7,136 & 0.0576 \\
\hline Difference (p-value) & & $(0.072)$ & & $(0.581)$ \\
\hline Other $=1$ & 65 & 0.0751 & 98 & 0.0776 \\
\hline Other $=0$ & 4,841 & 0.0598 & 7,220 & 0.0573 \\
\hline Difference (p-value) & & $(0.001)$ & & $(0.000)$ \\
\hline own $=1$ & 91 & 0.0763 & 142 & 0.0747 \\
\hline own $=0$ & 4,815 & 0.0597 & 7,176 & 0.0572 \\
\hline Difference (p-value) & & $(0.000)$ & & $(0.000)$ \\
\hline Director $=1$ & 125 & 0.0558 & 197 & 0.0576 \\
\hline Director $=0$ & 4,781 & 0.0601 & 7,121 & 0.0575 \\
\hline Difference (p-value) & & $(0.198)$ & & $(0.986)$ \\
\hline
\end{tabular}


Table 3. Standard deviation of discretionary accruals: OLS and median regressions.

The dependent variable is defined as the standard deviation (over the most recent 10-years) of the firm's discretionary accruals (estimated from equation 1 in the text) $\times 100$. Connected is a dummy variable set equal to 1 if the company is connected to a politician and 0 otherwise. A company is classified as politically connected if at least one of its large shareholders (anybody directly or indirectly controlling at least $10 \%$ of votes) or top directors (CEO, chairman of the board, president, vice-president, or secretary) is a member of parliament, a minister or a head of state, or is tightly related to a politician or party. For specific types of political connections, Gov takes the value 1 when the firm's connection is with a government official; MP takes the value 1 when the firm's connection is with a minister of parliament; Other takes the value 1 when the connection is a friendship or other indirect connection; Own takes the value 1 when the connection is through a major shareholder; Director takes the value 1 when the connection is through a director of the firm. Control is the voting stake held by the largest ultimate shareholder. Family is a dummy variable set equal to 1 if the largest shareholder is a family or individual who controls at least $20 \%$ of the votes and 0 otherwise. LnMkCap, is the natural log of the company's market capitalization in US dollars. SalGrwtSD is the standard deviation of the annual growth of sales. Salgrwt is the annual growth of sales. MTB is the ratio of market capitalization to book value of equity. Leverage is total debt as percentage of total assets. Rights is the interaction between the index of Anti-Director Rights, and the index of Legal Enforcement. Anti-Director Rights is taken from La Porta et al. (1998). "The index is formed by adding 1 when (1) the country allows shareholders to mail their proxy vote to the firm, (2) shareholders are not required to deposit their shares prior to the general shareholders' meeting, (3) cumulative voting or proportional representation of minorities in the board of directors is allowed, (4) an oppressed minorities mechanism is in place, (5) the minimum percentage of share capital that entitles a shareholder to call for an extraordinary shareholders' meeting is less than or equal to 10 percent, or (6) shareholders have pre-emptive rights that can be waived only by a shareholders' vote." Legal Enforcement is computed as the average across the degree of efficiency of the judicial system, an assessment of the rule of law, and corruption. Corruption is from Transparency International (www.transparency.org). The TI index measures the "degree to which corruption is perceived to exist among public officials and politicians. It is a composite index, drawing on 14 different polls and surveys from seven independent institutions, carried out among business people and country analysts, including surveys of residents, both local and expatriate." Corruption represents "the abuse of public office for private gain." The original index is rescaled from 0 to 10 , higher value for higher corruption. Industry dummies are defined at the 4-digit SIC level. Models (1) thru (7) are ordinary least squares estimates. In the regressions, standard errors are adjusting for heteroskedasticity and clustering of observations at the country level. P-values are reported in parentheses below the coefficient estimates. Model (8) is a median regression. In the median regression, standard errors are computed using bootstrap resampling (with 100 bootstrap replications) to control for heteroskedasticity (see Efron and Tibshirani, 1993, and Wu, 1986). P-values are reported in parentheses below the coefficient estimates. 
Table 3. Standard deviation of discretionary accruals: OLS and median regressions (Cont'd).

\begin{tabular}{|c|c|c|c|c|c|c|c|c|}
\hline & $(1)$ & (2) & (3) & (4) & $(5)$ & (6) & $(7)$ & $(8)$ \\
\hline Connected & $\begin{array}{l}1.0959 \\
(0.036)\end{array}$ & $\begin{array}{l}1.1804 \\
(0.004)\end{array}$ & $\begin{array}{l}0.8062 \\
(0.003)\end{array}$ & & & $\begin{array}{l}1.2849 \\
(0.007)\end{array}$ & $\begin{array}{l}1.2911 \\
(0.008)\end{array}$ & $\begin{array}{l}0.9681 \\
(0.003)\end{array}$ \\
\hline Gov & & & & $\begin{array}{l}1.8251 \\
(0.015)\end{array}$ & & & & \\
\hline $\mathrm{Mp}$ & & & & $\begin{array}{l}0.2774 \\
(0.435)\end{array}$ & & & & \\
\hline Oth & & & & $\begin{array}{l}2.2614 \\
(0.000)\end{array}$ & & & & \\
\hline Own & & & & & $\begin{array}{l}2.0885 \\
(0.001)\end{array}$ & & & \\
\hline Dir & & & & & $\begin{array}{l}0.3072 \\
(0.373)\end{array}$ & & & \\
\hline Control & & & & & & $\begin{array}{l}0.0266 \\
(0.454)\end{array}$ & & \\
\hline Control $^{2}$ & & & & & & $\begin{array}{l}-0.0002 \\
(0.618)\end{array}$ & & \\
\hline Family & & & & & & & $\begin{array}{l}0.6506 \\
(0.116)\end{array}$ & \\
\hline LnMkCap & $\begin{array}{l}-0.7074 \\
(0.000)\end{array}$ & $\begin{array}{l}-0.7044 \\
(0.000)\end{array}$ & $\begin{array}{l}-0.6049 \\
(0.000)\end{array}$ & $\begin{array}{l}-0.7030 \\
(0.000)\end{array}$ & $\begin{array}{l}-0.7017 \\
(0.000)\end{array}$ & $\begin{array}{l}-0.6125 \\
(0.000)\end{array}$ & $\begin{array}{l}-0.6201 \\
(0.000)\end{array}$ & $\begin{array}{l}-0.6594 \\
(0.000)\end{array}$ \\
\hline SalGrwtSD & $\begin{array}{l}0.0001 \\
(0.000)\end{array}$ & $\begin{array}{l}0.0001 \\
(0.000)\end{array}$ & $\begin{array}{l}0.0001 \\
(0.088)\end{array}$ & $\begin{array}{l}0.0001 \\
(0.000)\end{array}$ & $\begin{array}{l}0.0001 \\
(0.000)\end{array}$ & $\begin{array}{l}0.0001 \\
(0.000)\end{array}$ & $\begin{array}{l}0.0001 \\
(0.000)\end{array}$ & $\begin{array}{l}0.0001 \\
(0.947)\end{array}$ \\
\hline SalGrwt & $\begin{array}{l}0.0000 \\
(0.031)\end{array}$ & $\begin{array}{l}0.0000 \\
(0.195)\end{array}$ & $\begin{array}{l}0.0000 \\
(0.172)\end{array}$ & $\begin{array}{l}0.0000 \\
(0.211)\end{array}$ & $\begin{array}{l}0.0000 \\
(0.205)\end{array}$ & $\begin{array}{l}0.0085 \\
(0.006)\end{array}$ & $\begin{array}{l}0.0085 \\
(0.007)\end{array}$ & $\begin{array}{l}0.0000 \\
(0.996)\end{array}$ \\
\hline MTB & $\begin{array}{l}0.0175 \\
(0.001)\end{array}$ & $\begin{array}{l}0.0085 \\
(0.013)\end{array}$ & $\begin{array}{l}0.0065 \\
(0.005)\end{array}$ & $\begin{array}{l}0.0071 \\
(0.023)\end{array}$ & $\begin{array}{l}0.0074 \\
(0.020)\end{array}$ & $\begin{array}{l}0.0099 \\
(0.572)\end{array}$ & $\begin{array}{l}0.0117 \\
(0.482)\end{array}$ & $\begin{array}{l}0.0274 \\
(0.264)\end{array}$ \\
\hline Leverage & $\begin{array}{l}-0.0215 \\
(0.000)\end{array}$ & $\begin{array}{l}-0.0086 \\
(0.046)\end{array}$ & $\begin{array}{l}-0.0017 \\
(0.660)\end{array}$ & $\begin{array}{l}-0.0089 \\
(0.039)\end{array}$ & $\begin{array}{l}-0.0087 \\
(0.044)\end{array}$ & $\begin{array}{l}-0.0047 \\
(0.542)\end{array}$ & $\begin{array}{l}-0.0055 \\
(0.445)\end{array}$ & $\begin{array}{l}-0.0218 \\
(0.000)\end{array}$ \\
\hline Rights & $\begin{array}{l}-0.0009 \\
(0.973)\end{array}$ & $\begin{array}{l}-0.0120 \\
(0.625)\end{array}$ & & $\begin{array}{l}-0.0125 \\
(0.600)\end{array}$ & $\begin{array}{l}-0.0121 \\
(0.613)\end{array}$ & $\begin{array}{l}-0.0432 \\
(0.133)\end{array}$ & $\begin{array}{l}-0.0452 \\
(0.113)\end{array}$ & $\begin{array}{l}0.0018 \\
(0.691)\end{array}$ \\
\hline Corruption & $\begin{array}{l}0.0402 \\
(0.786)\end{array}$ & $\begin{array}{l}0.0070 \\
(0.963)\end{array}$ & & $\begin{array}{l}-0.0190 \\
(0.899)\end{array}$ & $\begin{array}{l}-0.0126 \\
(0.933)\end{array}$ & $\begin{array}{l}-0.1638 \\
(0.384)\end{array}$ & $\begin{array}{l}-0.1716 \\
(0.370)\end{array}$ & $\begin{array}{l}0.0805 \\
(0.028)\end{array}$ \\
\hline Intercept & $\begin{array}{l}15.2029 \\
(0.000)\end{array}$ & $\begin{array}{l}15.3685 \\
(0.000)\end{array}$ & & $\begin{array}{c}15.4619 \\
(0.000)\end{array}$ & $\begin{array}{c}15.4079 \\
(0.000)\end{array}$ & $\begin{array}{l}14.6782 \\
(0.000)\end{array}$ & $\begin{array}{l}15.0826 \\
(0.000)\end{array}$ & $\begin{array}{c}13.5768 \\
(0.000)\end{array}$ \\
\hline $\begin{array}{l}\text { Country dummies } \\
\text { Industry dummies }\end{array}$ & $\begin{array}{l}\text { No } \\
\text { No }\end{array}$ & $\begin{array}{l}\text { No } \\
\text { Yes }\end{array}$ & $\begin{array}{l}\text { Yes } \\
\text { Yes }\end{array}$ & $\begin{array}{l}\text { No } \\
\text { Yes }\end{array}$ & $\begin{array}{l}\text { No } \\
\text { Yes }\end{array}$ & $\begin{array}{l}\text { No } \\
\text { Yes }\end{array}$ & $\begin{array}{l}\text { No } \\
\text { Yes }\end{array}$ & $\begin{array}{l}\text { No } \\
\text { No }\end{array}$ \\
\hline $\begin{array}{l}\text { Number of obs. } \\
\text { Adjusted } R^{2}\end{array}$ & $\begin{array}{c}4,506 \\
0.1493\end{array}$ & $\begin{array}{c}4,506 \\
0.2469\end{array}$ & $\begin{array}{c}4,793 \\
0.3221\end{array}$ & $\begin{array}{c}4,506 \\
0.2492\end{array}$ & $\begin{array}{c}4,506 \\
0.2485\end{array}$ & $\begin{array}{c}2,030 \\
0.2743\end{array}$ & $\begin{array}{c}2,030 \\
0.2762\end{array}$ & $\begin{array}{c}4,506 \\
0.0926\end{array}$ \\
\hline
\end{tabular}


Table 4. Standard deviation of discretionary accruals: OLS and median regressions.

The dependent variable, is defined as the standard deviation (over the most recent 5 -years) of the firm's discretionary accruals (estimated from equation 1 in the text) $\times 100$. Independent variables are defined in Table 3. Models (1) thru (7) are ordinary least squares estimates. In the regressions, standard errors are adjusting for heteroskedasticity and clustering of observations at the country level. P-values are reported in parentheses below the coefficient estimates. Model (8) is a median regression. In the median regression, standard errors are computed using bootstrap resampling (with 100 bootstrap replications) to control for heteroskedasticity (see Efron and Tibshirani, 1993, and $\mathrm{Wu}, 1986)$. P-values are reported in parentheses below the coefficient estimates.

\begin{tabular}{|c|c|c|c|c|c|c|c|c|}
\hline & (1) & (2) & (3) & (4) & (5) & $(6)$ & (7) & (8) \\
\hline Connected & $\begin{array}{l}1.0899 \\
(0.049)\end{array}$ & $\begin{array}{l}0.9556 \\
(0.057)\end{array}$ & $\begin{array}{l}0.5492 \\
(0.187)\end{array}$ & & & $\begin{array}{l}1.2646 \\
(0.026)\end{array}$ & $\begin{array}{l}1.2586 \\
(0.026)\end{array}$ & $\begin{array}{l}0.7443 \\
(0.004)\end{array}$ \\
\hline Gov & & & & $\begin{array}{l}1.4355 \\
(0.077)\end{array}$ & & & & \\
\hline $\mathrm{Mp}$ & & & & $\begin{array}{l}0.0180 \\
(0.959)\end{array}$ & & & & \\
\hline Oth & & & & $\begin{array}{l}2.5982 \\
(0.000)\end{array}$ & & & & \\
\hline Own & & & & & $\begin{array}{l}2.0115 \\
(0.005)\end{array}$ & & & \\
\hline Dir & & & & & $\begin{array}{l}0.0942 \\
(0.749)\end{array}$ & & & \\
\hline Control & & & & & & $\begin{array}{l}0.0367 \\
(0.093)\end{array}$ & & \\
\hline Control $^{2}$ & & & & & & $\begin{array}{l}-0.0003 \\
(0.142)\end{array}$ & & \\
\hline Family & & & & & & & $\begin{array}{l}0.4439 \\
(0.187)\end{array}$ & \\
\hline LnMkCap & $\begin{array}{l}-0.7072 \\
(0.000)\end{array}$ & $\begin{array}{r}-0.6900 \\
(0.000)\end{array}$ & $\begin{array}{l}-0.6209 \\
(0.000)\end{array}$ & $\begin{array}{l}-0.6927 \\
(0.000)\end{array}$ & $\begin{array}{r}-0.6890 \\
(0.000)\end{array}$ & $\begin{array}{l}-0.6151 \\
(0.000)\end{array}$ & $\begin{array}{l}-0.6372 \\
(0.000)\end{array}$ & $\begin{array}{l}-0.5595 \\
(0.000)\end{array}$ \\
\hline SalGrwtSD & $\begin{array}{l}0.0002 \\
(0.000)\end{array}$ & $\begin{array}{l}0.0002 \\
(0.000)\end{array}$ & $\begin{array}{l}0.0001 \\
(0.027)\end{array}$ & $\begin{array}{l}0.0002 \\
(0.000)\end{array}$ & $\begin{array}{l}0.0002 \\
(0.000)\end{array}$ & $\begin{array}{l}0.0002 \\
(0.000)\end{array}$ & $\begin{array}{l}0.0002 \\
(0.000)\end{array}$ & $\begin{array}{l}0.0002 \\
(0.374)\end{array}$ \\
\hline SalGrwt & $\begin{array}{l}0.0000 \\
(0.142)\end{array}$ & $\begin{array}{l}0.0000 \\
(0.061)\end{array}$ & $\begin{array}{l}0.0000 \\
(0.783)\end{array}$ & $\begin{array}{l}0.0000 \\
(0.043)\end{array}$ & $\begin{array}{l}0.0000 \\
(0.076)\end{array}$ & $\begin{array}{l}0.0012 \\
(0.022)\end{array}$ & $\begin{array}{l}0.0011 \\
(0.022)\end{array}$ & $\begin{array}{l}0.0000 \\
(0.988)\end{array}$ \\
\hline МТВ & $\begin{array}{l}0.0035 \\
(0.338)\end{array}$ & $\begin{array}{l}0.0011 \\
(0.781)\end{array}$ & $\begin{array}{l}0.0004 \\
(0.900)\end{array}$ & $\begin{array}{l}0.0009 \\
(0.819)\end{array}$ & $\begin{array}{l}0.0009 \\
(0.811)\end{array}$ & $\begin{array}{l}0.0132 \\
(0.069)\end{array}$ & $\begin{array}{l}0.0138 \\
(0.050)\end{array}$ & $\begin{array}{l}0.0095 \\
(0.337)\end{array}$ \\
\hline Leverage & $\begin{array}{l}-0.0134 \\
(0.008)\end{array}$ & $\begin{array}{l}-0.0045 \\
(0.218)\end{array}$ & $\begin{array}{l}0.0035 \\
(0.186)\end{array}$ & $\begin{array}{l}-0.0051 \\
(0.179)\end{array}$ & $\begin{array}{r}-0.0048 \\
(0.188)\end{array}$ & $\begin{array}{l}-0.0018 \\
(0.692)\end{array}$ & $\begin{array}{r}-0.0030 \\
(0.467)\end{array}$ & $\begin{array}{l}-0.0182 \\
(0.000)\end{array}$ \\
\hline Rights & $\begin{array}{l}-0.0231 \\
(0.374)\end{array}$ & $\begin{array}{l}-0.0349 \\
(0.138)\end{array}$ & & $\begin{array}{l}-0.0352 \\
(0.126)\end{array}$ & $\begin{array}{l}-0.0349 \\
(0.132)\end{array}$ & $\begin{array}{l}-0.0558 \\
(0.023)\end{array}$ & $\begin{array}{l}-0.0614 \\
(0.016)\end{array}$ & $\begin{array}{l}-0.0186 \\
(0.000)\end{array}$ \\
\hline Corruption & $\begin{array}{l}-0.0953 \\
(0.527)\end{array}$ & $\begin{array}{l}-0.1234 \\
(0.436)\end{array}$ & & $\begin{array}{l}-0.1531 \\
(0.356)\end{array}$ & $\begin{array}{l}-0.1451 \\
(0.373)\end{array}$ & $\begin{array}{l}-0.2683 \\
(0.110)\end{array}$ & $\begin{array}{l}-0.2827 \\
(0.103)\end{array}$ & $\begin{array}{l}-0.0298 \\
(0.471)\end{array}$ \\
\hline Intercept & $\begin{array}{l}15.7190 \\
(0.000)\end{array}$ & $\begin{array}{l}15.8017 \\
(0.000)\end{array}$ & & $\begin{array}{l}15.9520 \\
(0.000)\end{array}$ & $\begin{array}{l}15.8658 \\
(0.000)\end{array}$ & $\begin{array}{l}15.0163 \\
(0.000)\end{array}$ & $\begin{array}{l}15.9436 \\
(0.000)\end{array}$ & $\begin{array}{l}12.5822 \\
(0.000)\end{array}$ \\
\hline $\begin{array}{l}\text { Country dummies } \\
\text { Industry dummies }\end{array}$ & $\begin{array}{l}\text { No } \\
\text { No }\end{array}$ & $\begin{array}{l}\text { No } \\
\text { Yes }\end{array}$ & $\begin{array}{l}\text { Yes } \\
\text { Yes }\end{array}$ & $\begin{array}{l}\text { No } \\
\text { Yes }\end{array}$ & $\begin{array}{l}\text { No } \\
\text { Yes }\end{array}$ & $\begin{array}{l}\text { No } \\
\text { Yes }\end{array}$ & $\begin{array}{l}\text { No } \\
\text { Yes }\end{array}$ & $\begin{array}{l}\text { No } \\
\text { No }\end{array}$ \\
\hline $\begin{array}{l}\text { Number of obs. } \\
\text { Adjusted } R^{2}\end{array}$ & $\begin{array}{c}6,519 \\
0.1082\end{array}$ & $\begin{array}{c}6,519 \\
0.1766\end{array}$ & $\begin{array}{c}6,919 \\
0.2282\end{array}$ & $\begin{array}{c}6,519 \\
0.1796\end{array}$ & $\begin{array}{c}6,519 \\
0.1783\end{array}$ & $\begin{array}{c}3,114 \\
0.2187\end{array}$ & $\begin{array}{c}3,114 \\
0.2168\end{array}$ & $\begin{array}{c}6,519 \\
0.0604\end{array}$ \\
\hline
\end{tabular}


Table 5. Robustness tests: Two-stage probit least squares.

Regressions (1) and (3) are first stage probit regressions, in which the dependent variable is Connected. Connected is a dummy variable set equal to 1 if the company is connected to a politician and 0 otherwise. A company is classified as politically connected if at least one of its large shareholders (anybody directly or indirectly controlling at least $10 \%$ of votes) or top directors (CEO, chairman of the board, president, vicepresident, or secretary) is a member of parliament, a minister or a head of state, or is tightly related to a politician or party. Regressions (2) and (4) are second stage (OLS) estimates, in which I_Connected is the predicted value of Connected estimated in the first stage. The instrumental variable used, Capital, is a dummy variable set equal to 1 if the company is headquartered in the capital of its country, and 0 otherwise. In regression (2), the dependent variable, Stresid, is defined as the standard deviation (over the most recent 10-years) of the firm's discretionary accruals (estimated from equation 1 in the text) $\times 100$. In regression (4), the dependent variable is defined as the standard deviation (over the most recent 5-years) of the firm's discretionary accruals (estimated from equation 1 in the text) $\times 100$. Independent variables are defined in Table 3 . P-values are reported in parentheses below the coefficient estimates. The estimation is performed using the cdsimeq command in Stata (Maddala, 1983, Keshk, 2003).

\begin{tabular}{lcccc}
\hline & $\begin{array}{c}(1) \\
\text { First stage } \\
\text { (Probit) }\end{array}$ & $\begin{array}{c}(2) \\
\text { Second stage } \\
\text { (OLS) }\end{array}$ & $\begin{array}{c}(3) \\
\text { First stage } \\
\text { (Probit) }\end{array}$ & $\begin{array}{c}\text { Second stage } \\
\text { (OLS) }\end{array}$ \\
\hline Dep. variable: & Connected & Stresid (10 yrs) & Connected & Stresid (5 yrs) \\
\hline Capital & 0.6413 & & 0.6756 & \\
I_Connected & $(0.000)$ & & $(0.000)$ & \\
& & 1.1538 & & 1.5369 \\
LnMkCap & & $(0.000)$ & $0.000)$ \\
SalGrwtSD & 0.1157 & -0.8250 & 0.1007 & -0.8268 \\
& $(0.000)$ & $(0.000)$ & $(0.000)$ & $(0.000)$ \\
SalGrwt & 0.0000 & 0.0001 & 0.0000 & 0.0002 \\
& $(0.876)$ & $(0.000)$ & $(0.858)$ & $(0.000)$ \\
MTB & 0.0001 & 0.0028 & 0.0001 & 0.0008 \\
& $(0.925)$ & $(0.001)$ & $(0.164)$ & $(0.003)$ \\
Leverage & -0.0002 & 0.0095 & -0.0083 & 0.0213 \\
& $(0.976)$ & $(0.197)$ & $(0.036)$ & $(0.001)$ \\
Rights & 0.0015 & -0.0002 & 0.0000 & 0.0001 \\
& $(0.252)$ & $(0.913)$ & $(0.946)$ & $(0.101)$ \\
Corruption & -0.0081 & 0.0162 & -0.0075 & 0.0006 \\
Intercept & $(0.012)$ & $(0.005)$ & $(0.009)$ & $(0.916)$ \\
& 0.0838 & -0.1133 & 0.0845 & -0.2243 \\
Number of obs. & $(0.000)$ & $(0.010)$ & $(0.000)$ & $(0.000)$ \\
\hline & -3.3803 & 18.1796 & -3.1427 & 19.1365 \\
& $(0.000)$ & $(0.000)$ & $(0.000)$ & $(0.000)$ \\
\hline
\end{tabular}


Table 6. Discretionary accruals and the cost of debt: Univariate analysis.

The table reports the average cost of debt for companies falling into different groups. Cost of Debt, is the ratio of a firm's interest expense in year $t$ (in our case 2005) over the average interest bearing obligations outstanding as of the end of year $\mathrm{t}-1$ and $\mathrm{t} \times 100$. This ratio is converted in U.S. dollar terms using the covered interest parity. Connected is a dummy variable set equal to 1 if the company is connected to a politician and 0 otherwise. A company is classified as politically connected if at least one of its large shareholders (anybody directly or indirectly controlling at least $10 \%$ of votes) or top directors (CEO, chairman of the board, president, vicepresident, or secretary) is a member of parliament, a minister or a head of state, or is tightly related to a politician or party. Stresid (10 yrs) is defined as the standard deviation (over the most recent 10-years) of the firm's discretionary accruals (estimated from equation 1 in the text). Stresid $(5 \mathrm{yrs})$ is defined as the standard deviation (over the most recent 5-years) of the firm's discretionary accruals (estimated from equation 1 in the text). The first number is the average cost of debt (\%); the second figure (in parenthesis) is the p-value of a t-stat for difference from zero; the third number is the number of observations.

\begin{tabular}{lcc}
\hline \multicolumn{1}{c}{ Panel A: Accruals quality proxy: Stresid (10 yrs) } & Connected & Non-connected \\
Stresid (10 yrs) $\geq$ sample median & $6.99 \%$ & $7.84 \%$ \\
& $(0.00)$ & $0.00)$ \\
& 104 & 2,015 \\
Stresid $(10 \mathrm{yrs})<$ sample median & $5.56 \%$ & $6.00 \%$ \\
& $(0.00)$ & $(0.00)$ \\
& 81 & 2,037 \\
Difference & $1.43 \%$ & $1.84 \%$ \\
& $(0.04)$ & $(0.00)$ \\
& 185 & 4,052 \\
\hline & Panel B: Accruals quality proxy: Stresid $(5 \mathrm{yrs})$ & \\
& Connected & Non-connected \\
Stresid $(5$ yrs $) \geq$ sample median & $6.92 \%$ & $7.74 \%$ \\
& $(0.00)$ & $(0.00)$ \\
Stresid $(5$ yrs $)<$ sample median & 138 & 2,658 \\
& & \\
& $5.76 \%$ & $5.95 \%$ \\
Difference & $(0.00)$ & $(0.00)$ \\
& 114 & 2,682 \\
& $1.16 \%$ & $1.79 \%$ \\
& $(0.04)$ & $(0.00)$ \\
& 252 & 5,340 \\
\hline
\end{tabular}


Table 7. Discretionary accruals and the cost of debt.

The dependent variable, Cost of Debt, is the ratio of a firm's interest expense in year $\mathrm{t}$ (in our case 2005) over the average interest bearing obligations outstanding as of the end of year $t-1$ and $t \times 100$. This ratio is converted in U.S. dollar terms using the covered interest parity. Stresid (10 yrs) is defined as the standard deviation (over the most recent 10-years) of the firm's discretionary accruals (estimated from equation 1 in the text). Stresid (5 yrs) is defined as the standard deviation (over the most recent 5-years) of the firm's discretionary accruals (estimated from equation 1 in the text). Leverage is total debt as percentage of total assets as of year end t-1; LnMkCap is measured as the natural log of the company's market capitalization in US dollars, as of year end t-1; volatility is the standard deviation (SalGrwtSD) of sales growth during 1994-2005 (or the shorter period for which the data is available). ROA is the ratio of operating income (after taxes) to total assets in year t-1; the Interest Coverage Ratio is the ratio of operating income to interest expense in year $t-1$. Because of the presence of outliers, we toss out companies with a cost of debt in the top/bottom percentile, as well as companies with an interest coverage ratio in the top/bottom percentile. All models are ordinary least squares estimates. In the regressions, standard errors are adjusting for heteroskedasticity and clustering of observations at the country level. P-values are reported in parentheses below the coefficient estimates.

\begin{tabular}{lcccc}
\hline & $(1)$ & $(2)$ & $(3)$ & $(4)$ \\
& Non-connected & Connected & Non-connected & Connected \\
\hline Stresid (10 yrs) & 24.7148 & -1.2526 & & \\
Stresid (5 yrs) & $(0.0000)$ & $(0.8550)$ & & -0.0266 \\
& & & 23.0416 & $(0.9950)$ \\
Leverage & & & $(0.0000)$ & -0.0456 \\
& -0.0505 & -0.0625 & -0.0260 & $(0.0280)$ \\
LnMkCap & $(0.0010)$ & $(0.0910)$ & $(0.0340)$ & -0.3318 \\
& -0.1552 & -0.3663 & -0.1613 & $(0.0130)$ \\
SalGrwtSD & $(0.1410)$ & $(0.0880)$ & $(0.1220)$ & -0.0002 \\
& -0.0000 & -0.0002 & -0.0000 & $(0.0000)$ \\
ROA & $(0.0000)$ & $(0.0000)$ & $(0.0350)$ & -0.0318 \\
& -0.0051 & -0.0453 & -0.0002 & $(0.5750)$ \\
Interest Cov. Ratio & $(0.7300)$ & $(0.5330)$ & $(0.9180)$ & 0.0029 \\
& -0.0003 & 0.0051 & -0.0003 & $(0.6460)$ \\
Intercept & $(0.8520)$ & $(0.5540)$ & $(0.8470)$ & 12.1431 \\
& 8.7529 & 13.3557 & 8.2945 & $(0.0000)$ \\
\hline Number of obs. & $(0.0000)$ & $(0.0030)$ & $(0.0000)$ & 245 \\
Adjusted R & 3,947 & 182 & 5,164 & 0.0841 \\
\hline
\end{tabular}

